\title{
Green innovations in logistics supporting the development of innovative green technologies, processes, products and services in companies in Slovakia
}

\author{
Klaudia Gubová ${ }^{1, *}$ \\ ${ }^{1}$ Department of Production management and Logistics, Faculty of Business Management, University \\ of Economics in Bratislava, Dolnozemská 1/b, 85235 Bratislava, Slovak republic
}

\begin{abstract}
Significant changes on global markets influence behaviour of businesses as well as position of logistics. As logistics represents one of the parts in business process, it is important to monitor its direction and development. Modern management in a business, application of new information, technologies and systems, stricter legislation requirements, they all move business logistics forward. Logistics systems are being constantly modernised. Modernisation greatly considers automation, robotics, development of artificial intelligence and digitalisation. Rapid development of technologies and systems causes that future form of logistics, together with technologies, will represent important source of competitive advantage on the market. The main objective of the scientific paper is to identify, analyze, evaluate and generalize the use of green logistics in Slovakia in order to achieve the competitiveness of the company on the market. Green logistics will be one of the most dominant trends in business logistic in forthcoming period.
\end{abstract}

\section{Introduction}

In today's dynamically developing world there are many economic, social, technical and political changes. Their nature and extent is determined by factors influenced by economic development and economic growth. As a result of globalization, there is a sharp increase in competition. Globalization of markets and business brings the same prerequisites for access to information, resources and technology. We see that the "world" is getting smaller and distances are minimized by information and communication technologies. [1].

Recently, there have been significant changes and advances in logistics. Its competences within the company have gradually expanded and have taken on more and more activities, thus beginning to fulfill an essential role in the management of the company. Globalization, economic changes, turbulent development of information and communication technologies,

\footnotetext{
${ }^{*}$ Corresponding author: Klaudia Gubová, Assoc.Prof. Ing. PhD., University of Economics in Bratislava, Department of Production management and Logistics, Dolnozemská cesta 1/b, 85235 Bratislava, klaudia.porubanova@euba.sk
} 
automation of production, development of industrial revolutions, especially the Fourth Industrial Revolution contributed to the new form of logistics [2].

The onset of digitalization in all business areas started to show major changes. New global markets, business models, advances in information and communication technologies and innovation are arising in each business area. Currently, Industry 4.0 dominates the world. It brings not only revolutionary changes in production and logistics, but fundamentally changes the society itself and the economy of the country. Industry 4.0 is based on the idea of linking digitization and automation using the latest technology [3]. Fourth industrial revolution and changes in production systems will bring changes in transportation logistics. New European legislation changes, industrial market is becoming more dynamic, innovations in logistics are its natural part. Part of ensuring effective transportation within the process of decision making, it is not only transportation distance that has an essential role, but it is also available transportation means. There are still new and new logistics centres being built by traffic junctions. This trend supports not only positive development in automobile segment, but also in dynamic sector of e-commerce. Emphasis on application of logistics innovations is not concentrated exclusively on production businesses, but it regards the entire chain - from suppliers through producer up to customer. Many businesses concentrate not only on optimisation of production processes, but also on implementation and development of innovations in logistics. They have understood that optimisation is possible also in logistics. Innovation is a necessity for all logistics processes not only via atomisation of transport; however atomisation needs to be transferred also to information processes and warehouses. The reason for automation is simple. The application of new technologies is pushing manufacturing to a new revolution. The essence of Industry 4.0 is connecting devices to communicate with each other. Industry 4.0 is mainly used in industry, but has a great impact on other areas of the economy as well as on society as a whole [4]. The outcomes of the so-called Industry 4.0, or smart manufacturing, are the object of high expectations. Today, many logistics enterprises take the attention to the importance of big data and claim that Data Analytics will be one of the key skills of the twenty-first century.

\subsection{Logistics innovation}

Currently, innovations represent factor influencing not only competitive ability of business, but also population quality of life, environmental behaviour of citizens and businesses, social sphere, informational literacy of business. Innovations are considered to be result of utilisation of different stimulus, tools, techniques, which in practical application represent, apart from satisfaction of basic needs, something more for consumer „over added value".

When we think about future, we believe in future of progress. Technology offers businesses new and better way to perform better and more effectively. After investigating different spectres for implementing innovation trends in logistics we might establish that in narrower sense technology development is one of the directions for expected progress in innovations sphere and globalisation is the second most considered factor. Business is able to utilise both ways of progress with an aim to achieve advancement in business at once, separately and all at once.

Nowadays, we can see huge differences between developed and developing countries in quality of life as well in technological progress. We can establish, that developed countries 
have discovered, developed and achieved everything the world needs, while developing countries are far behind. Here, globalisation did not assist to balanced development of different parts of the world. Globalisation profiles areas narrowly and has not moved its boarders to developing countries. Innovation in one sphere of business initiates chain of activities and changes in other areas with either positive or negative impact. Currently, logistics businesses note innovation development and gradually implement innovations into their logistics processes. Development of technologies and technics, implementation of new logistics innovations move and broaden boarders of globalisation, which are development of Internet and other communication, information and transformation technologies. There is polarisation between those able and willing to adapt to constant changes and those who are not. Also, there is growing difference between those with an access to new technologies, information and those who do not have this access. We can confirm that future development, progress will be in technologies. Globalisation is aimed to achieve sustainability; however, it would not be sustainable without technology development.

Entrance of internet and dynamic technics expansion supported growth of space for service innovations. Nowadays, the biggest competitive strength is hidden in information. Information moves the world of innovations. Innovation is an enormous power, an important factor for survival, growth and business prosperity. Innovation is now recognized as the key to bridging the gap between technology and business strategy.

The innovation concept can create confusion with other similar definitions, such as improvement, invention and discovery, because, according to Schumpeter (op. cit.) innovation is the launching of a new product or improvement of what already exists, or the introduction of a new method of production, i.e. innovation in the process, the opening up of a new market, a new source of raw materials or semi-manufactured goods, and a new form of industrial organization.[5] Fast changes in technologies and technics cause that companies do not have time to devote time to research and development of new products and services. Tangible assets are very quickly morally depreciated, which is a result of fast technological development. There is a rapid obsolesce of products and patterns. Innovation viability is conditioned by factors such as: dynamic technical progress, ever changing competitive environment and trends in behaviour of consumers. Majority of businesses lead their internal politics following ,never try anything new as first, only things which are proved and certified." [6] The most suitable imitation sphere is technical sector; however there are many opportunities for imitating in all sectors.

The logistics process for the management of all physical flows both in and between companies. It is a transversal process that concerns all the services of a company and which includes in the reflection the partners. Innovation has been argued to be a strong driver of customer satisfaction in the logistics industry. [7] Industrial production and logistics fulfil customer demands. Since those change over time, production paradigms also change. With the current turn towards more individual products, new ways of production and logistics are needed in order to avoid an increase of costs and competitive disadvantages on global market. [8] At the moment, innovative management technologies are emerging, business models are being revised, latent management reserves are not used, the best world experience is being studied and the possibility of using it in Russian conditions is defined taking into account adjustments to existing realities. [9] Although manufacturing and logistics have gained maturity over the last decades, saturated markets and new customer demands put pressure on logistics systems, turning them from complicated to complex ones.[10] Important drivers are shortening product lifecycles, globalisation of markets, 
demographic change and customer demands to offer individualised products, also accompanied by sustainability aspects. [11] These drivers form a dynamic and challenging environment for enterprises, which, in manufacturing, can be addressed with Industry 4.0. For companies, indicators are indispensable to manage and control the plethora of innovative ideas and concepts that are submitted to them. The defined selection criteria are equally important for an efficient resource allocation and performance evaluation in each phase of the innovation process. [12]

To optimize the provision of logistics services, it is necessary to assess the quality of transport services using a system of indicators ranked according to their importance to passengers and minimize negative differences between expected customer and actual values of road transport quality indicators. This requires constant monitoring of environmental factors, competitors and own resources, quality control of logistics services, and passenger satisfaction with completed orders. [13] The management of the transport company should set a specific set of quality control goals for the staff, including the precise implementation of all aspects of customer orders, in compliance with transportation time, continuous monitoring of meeting passengers' requirements for the logistics service system, optimization of logistics costs to maintain the required level of transport services, integration of available information technology resources and the practical implementation of advanced technology. [14]

\subsection{Green logistics innovations}

Currently, development of innovations in logistics and ecologisation are connected with the income of new forms and attitudes of businesses towards decreasing environmental impact. Reverse logistics is an important area in achieving environmental goals in society and especially in the company. In general, the definition of reverse logistics is determined by its division into reverse logistics at macro or microeconomic level, their mutual coordination and integration [15]. Reverse logistics, from point of development and implementation of innovations into logistics businesses, creates one of the basic elements for circular economy. First impulse is „eco thinking“ Life Cycle Thinking (LCT) which means considering environmental, social, economic aspects and their impact on product during their entire life cycle (from obtaining raw materials, through processing materials, production, distribution, utilisation, repairing and maintenance and disposal and recycling) and value chain from cradle to the grave. Main objectives of LCT thinking of life cycle are decreasing resource consumption and product emissions on environment and improving their social and socio-economic performance during their life cycle. Stated goals are achievable for logistics businesses in implementation of environmental politics and implementation of circular economy into managing relationship management with business subjects.

Green Logistics represents trend in logistics which deals with production planning, material management and goods distribution in sustainable ecological rate with regards of factors influencing environment and society. Green logistics concentrates on ecological, economic and social aspects.[16] Increasing environmental concern from customers, buyers, communities, and government regulations have forced companies to implement Green Supply Chain Management (GSCM) and green innovation. GSCM and green innovation have strategic interconnection in developing new green product.[17] Also "the construction sector constantly offers new products, more effective technologies and novel solutions aimed at improvement of the quality of human habitats and wider distribution of technologies. Currently, effective technologies that require less time and costs for production, installation and use are gaining greater significance. Among them are 
construction materials and technologies with increasingly popular sustainability features." [18] Green supply chain management (GSCM) is a strategy for sustainable development in today's competitive markets, which aims to simultaneously achieve financial benefits and reduce environmental risks.[19]

\section{Methods}

The main objective of the scientific paper is to identify, analyze, evaluate and generalize the use of green logistics in Slovakia in order to achieve the competitiveness of the company on the market.

Green logistics will be one of the most dominant trends in business logistic in forthcoming period. The reason behind it is mostly ecological thinking of businesses and formation of business programs for environmental protection as well as maintaining competitive ability for the future. It was confirmed also by tested hypothesis which states that on level of importance $\alpha=0,05$ there is statistically important dependence between enforcement of environmental politics and improvement of Green logistics.

For a long time sustainability has been one of the most important questions of these days. The biggest contribution towards sustainability in the world is Green logistics. Green logistics contributes towards environmental protection with an aim to support ecological means of production and transportation. We believe that businesses promoting environmental politics try to improve green logistics in their business.

In the research, there were 135 businesses addressed, feedback was received from 95 businesses that filled out the questionnaire. We can appreciate high return 70,4\% and willingness of businesses to fill out the questionnaire.

\section{Results and Discussions}

Innovations developing in logistics on the side of demand and offer, such as decreasing labour and growing importance of logistics in electronic stores, leading to wide acceptance of robotics and automation in warehouses. Even though logistics affectivity is rising, there are potential social consequences as a result of threat of losing millions of working places in logistics. Another innovation supporting development of logistic innovative trends is Blockchain. It is permanent digital record of transactions saved in decentralised computer network. It has advantages in many parts of this industry, such as cost savings (paperless transactions); data verification; „Intelligent contracts“; responsibility and consonance.

Many new technologies, daily entering markets in different areas of goods transportation, forwarding and storage increase development potential of other referring innovations in logistics as well as other market sectors. Devices, autonomously detecting when they need replacement parts, production systems, which perform their own quality control during operations and hence decrease control costs, robots, which autonomously recognize and move components. These scenarios are gradually becoming reality in industrial production. They are based on future technologies such as artificial intelligence (AI) and computing technics. These offer many opportunities for industry, because they open new business models and potential for productivity increasing. Hence, they are essential in order to secure competitiveness for industrial businesses in future world.

Implementation and application of selected logistics innovations leads towards reduction of costs, time, waste, decreases risks, simplifies decision making processes and leads towards development of new products with ecological aspect. 
Green logistics requires particular attention. Changes in people's behaviour, technological advancement and industrial revolution significantly impacted environment. Current condition in form of climate changes, global warming, pollution of water, soil, air and future forecasts indicate we need to think ecologically - "green". Hence it is necessary for people to manage environment wisely and on business level prevent negative influences impacting environment to a great degree. From the research we learnt that businesses accept Green logistics very little, its assessment in Likert scale was usually in smaller numbers. Therefore, we would like to warn businesses about this situation. Businesses must realise their relationship to environment and act more considerable and develop more activities in sphere of Green logistics on business level.

Green logistics was dealt with also within questionnaire. Green logistics is very much applied only by 5,33\% of Slovak enterprises. Based on research results $19,33 \%$ of enterprises have neutral opinion towards application of Green logistics. Enterprises improve Green logistics with share of $9 \%$ and neutral opinion was expressed by $18 \%$ of participants.

After summarizing these findings, enterprises should focus on activities in logistics leading towards more considerate behaviour to environment on business level. It is crucial for businesses to consider environment when starting enterprises, in individual parts of business logistics, certain internal logistics processes as packaging and packages. Last but not least, it is important to increase awareness of employees about Green logistics in form of lectures, employee activities and visual management in the business. Enterprises could organise employee Eco activities such as tree planting on premises, improved waste labelling in enterprises and others. It is not possible to create a singular model of how Green logistics should function in the enterprises, because it depends on its size and focus of activities. There is difference between Green logistics in enterprise offering services in transportation and Green logistics of a production business.

Out of mentioned business examples it is appropriate to focus on utilisation and operation of ecological transportation means. Within a enterprise it could be transportation means in form of electro mobiles. Outside of the enterprises it would be vehicles which release less CO2 into atmosphere. It would be suitable to discuss topic of electro mobiles in Slovakia more and to enforce them on business level, because in 2015 there were only 49 electro mobiles registered in Slovakia, however, number of all registered personal vehicles registered in 2015 reached almost 80 thousand. Also we would suggest to utilise also railway transport not only automobiles for transportation of goods and products. Enterprises could realise packaging and storage via plastics packaging which can be used until they are not physically deteriorating for internal logistics processes. Enforcement of Green logistics is possible also by disburdening businesses of paper administration. Its removal was mentioned back in $80^{\text {th }}$ years of last century within business relationship B2B.

\section{Conclusion}

Changes in people's behaviour, technological advancement and industrial revolution significantly impacted environment. Current condition in form of climate changes, global warming, pollution of water, soil, air and future forecasts indicate we need to think ecologically - "green". If you want businesses to survive in a competitive environment, they must improve their business processes, to prosper, to make changes and be open to new opportunities [20]. Hence it is necessary for people to manage environment wisely and on business level prevent negative influences impacting environment to a great degree. From the research we learnt that enterprises accept Green Logistics very little, its 
assessment in Likert scale was usually in smaller numbers. Therefore, we would like to warn enterprises about this situation. Businesses must realise their relationship to environment and act more considerable and develop more activities in sphere of Green Logistics on business level.

Green logistics will be one of the most dominant trends in business logistic in forthcoming period. The reason behind it is mostly ecological thinking of businesses and formation of business programs for environmental protection as well as maintaining competitive ability for the future. Extending product life is an important part of a circular economy because it brings economic value and material savings. The product design approach to the system should take into account both forward and reverse logistics, as well as a new value that is based on maximizing customer service through multiple lives.

Industry 4.0 provides a technological drive for innovation, while a circular economy is seen as a driving force for the introduction of an industrial framework in 2030. It can not be a circular economy without the $4^{\text {th }}$ Industrial Revolution - it can not be socially useful and sustainable $4^{\text {th }}$ industrial revolution without improving the circular economy.

\section{Acknowledgments}

The article is a partial output of research project VEGA No. 1/0375/20 „, New dimension in the development of production management and logistics under the influence of Industry 4.0 in enterprises in Slovakia“. 


\section{References}

1. P. Richnák, Globalization and its impact on the present concepts in company management. Globalization And Its Socio-Economic Consequences. Part 2: Proceedings: 15Th International Scientific Conference: 7Th-8Th October 2015, Rajecke Teplice, Slovak Republic, 608-616.

2. P. Richnák, Nové smery rozvoja v logistike. Journal Of Innovations And Applied Statistics: Vedecký Internetový Časopis, 9, 2, 95-103.

3. P. Richnák, The Current Trends in the Industry - Industry 4.0 in Slovak Enterprises. Dokbat 2019: International Bata Conference, 916-925.

4. P, Richnák, J. Sármány, Vývoj a postavenie Industry 4.0 vo svete a na Slovensku. Manažment Podnikania A Vecí Verejných: Vedecko-Odborný Časopis, 14, 2, 3-9.

5. P. Hamilton, K. A. Getulio, T. Takeshy, Innovation and technology processes in micro and small business. Cogent Business \& Management, 6 (2019)

6. O. Shenkar, Imitátori. Bratislava : EASTONE BOOKS, 2011. 1p. ISBN 978-808109-164-3.

7. S. Bellingkrodt, C. M Wallenburg, The role of external relationships for LSP innovativeness: A contingency approach. Journal of Business Logistics, 34, 3 (2013)

8. E. Hofmann, M. Rüsch, Industry 4.0 and the Current Status as Well as Future Prospects on Logistics. Computers in Industry, 89 (2017)

9. U. Stephan, M. Patterson, C. Kelly, J. Mair, Organizations driving positive social change processes. Journal of Management, 42, 5 (2016)

10. T. Bauernhansl, Die Vierte Industrielle Revolution - Der Weg in ein Wertschaffendes Produktionsparadigma. Industrie 4.0 in Produktion, Automatisierung und Logistik. Springer Vieweg, Wiesbaden. 2014, pp. 5-35. ISBN 978-3-658-04682-8.

11. M. Jubiz-Diaz, A. Santander-Mercado, J. E. Candelo-Becerra, A Multi-item Multipackaging Model to Minimise Cost of Lost Units, Unpacking Cost and $\mathrm{CO} 2$ Emissions. International Journal of Production Research, (2019)

12. V. Dewangan, M. Godse, Towards a holistic enterprise innovation performance measurement system. Technovation 34, 9 (2014)

13. C. E. Helfat, J. A. Martin, Dynamic managerial technologies for review, Journal of Management 41, 5 (2015)

14. A. K. Vadera, P. Mishra, M. G. Pratt, Constructive deviance in organizations: integrating and moving forward. Journal of Management 39, 5 (2013)

15. A. Dupal', P. Richnák, Vybrané trendy a koncepcie v procesnej orientácii podnikovej logistiky. Ekonomika A Manažment: Vedecký Časopis Fakulty Podnikového Manažmentu Ekonomickej Univerzity V Bratislave, 14, 3, 8-19.

16. J. P. Rodrigue, C. Comtois, B. Slack, The Geography of Transport Systems. 4th Edition. New York: Routledge, 2017. p. 306. ISBN 978-0415483247.

17. N. A. Seman, N. Zakuan, A. Jusoh, M. S. Arif, M. Z. SAMAN, The relationship of green supply chain management and green innovation concept. Procedia-Social and Behavioral Sciences. 57 (2012) 
18. S. Kildiene, E. K. Zavadskas, J. Tamošaitiene, Complex assessment model for advanced technology deployment. Journal of Civil Engineering and Management 20, 2 (2014)

19. M. Hajikhani et al. Considering on green supply chain management drivers, as a strategic organizational development approach, Malaysian perspective. Australian Journal of Basic and Applied Sciences. 6, 8 (2012)

20. P. Richnák, Usage of Logistics Technologies in Slovak Enterprises. Logi-Scientific Journal On Transport And Logistics, 10, 2, 94-104. 